\title{
An Islamic View on Contraception and Abortion
}

\author{
Dr. Mohammed Ali Albar, D.M., M.R.C.P. \\ Jeddah, Saudi Arabia
}

DOI: http://dx.doi.org/10.5915/21-2-5527

\begin{abstract}
Absiract
Though procreation is considered the most important function of marriage, millions of women use some means of contraception and even resort to abortion. Medical reasons constitute only a small proportion of the actual number of cases, the rest being for social and other reasons.

Islam encourages limilless procreation within wedlock; nevertheless, it does not ban the use of temporary means of contraception. The use of permanent means of contraception is not allowed unless pregnancy would pose a threat 10 the health or life of the expectant mother. Similarly, abortion is not allowed unless the life or health of the pregnant woman is at real risk.

Serious congenital anomalies of the fetus may be considered as an indication to perform abortion provided it is done in the first 40 days of pregnancy. A more lenient view would extend it to the first 120 days of pregnancy, computed from the time of fertilization.

This paper discusses the different viewpoints of Islamic jurists on these issues, and compares them with the acrual practice in Muslim countries.
\end{abstract}

Key words: Islam, contraception, sterilization, abortion

Islarn, Christianity and Judaism look to procreation as an integral part of marriage. A verse in the Holy Bible reads, "God said to both Adam and Eve: Be fruitful and increase in number, fill the earth and subdue it." 1

The Catholic Church holds the most conservative and stringent viewpoint against any means of contraception, except the physiological regulation of the menstrual cycle and abstention from sex during the time of ovulation (rhythm method).

Protestants and most other churches allow all methods of contraception, some even including first irimester abortion.

In Islam, procreation is not only an integral part of matrimony but, it is considered an act of worship, as it fulfills Alfah's orders of multiplying and filling the

Frum the King Fahd Medical Research Center, Faculty of Medicine, King Abdulaziz University, Jeddah, Saudi Arabia.

Reprint requests: Dr. Mohammed Ali Albar, P.O. Box 2631, Jeddah, 21461, Saudi Arabia. earth with good offspring. The Holy Qur'ān proclaims:

"O Mankind. Be conscious of your Sustainer, who has created you out of one living entity, and out of it created its mate, and of the two spread abroad a multitude of men and women."'

"And Allāh has given you mates of your own kind, and has given through your mates children and grandchildren.",

Prophet Muhammad (PBUH) said to all Muslims:

"Get married, beget and multiply, because I will be proud of you among all nations."

He also said:

"O Men marry the kind and fertile, for I will be proud of your numbers among other nations." "s,6

Though Islamic teachings encouraged procreation within matrimonial bondage, it did not altogether 
prevent the use of contraception.

At the time of the Prophet (PBUH), a companion of the Prophet called 'Abū Sa'id al-Khudri (may Allāh be pleased with him) asked the Prophet about " "azl" (coitus interruptus). The Prophet said: "It is not forbidden that you may do 'azl. But whatever a soul that would be created by Allāh, will be created until doomsday." ",

Another companion of the Prophet told him that he is practicing 'azl. The Prophet (PBUH) said: "Practice whatever you may wish, but she will get whatever is ordained for her by Allāh." The man came back after a while, telling the Prophet that she became pregnant. The Prophet then said: "Didn't I tell you that she will get whatever is destined for her by Allāh?" "B-10

The four schools of Islamic Sunni jurisprudence, Māliki, Hanbali, Hanafí and Shāfíi, all allow 'azl (coitus interruptus). The Hanbali and Mäliki schools indicate that the wife should agree to 'azl, because she has a right in procreation.

The Islamic jurists would divide the contemporary means of contraception into three categories:

\section{1) Permanent type of contraception}

There are some drastic means which cause permanent contraception, e.g., hysterectomy, ovariectomy, orchidectomy. Such methods had never been resorted to, for the sole purpose of contraception. They are usually performed for ailments and serious diseases of these organs. On the other hand, there are procedures that are designed for the sole purpose of sterilization, i.e., subal ligation in the female and vasectomy in the male.

Tubal ligation is often practiced in multiparous women who suffer from diabetes, renal disease, hypertension or other medically disabling conditions. Sometimes vasectomy is practiced on the husband instead of ligation of the uterine tubes of the wife. The Indian government in the 1970s legalized compulsory vasectomy of males with more than 2 children, in order to curb population "explosion" in India. Vasecromy is disliked by male spouses, especially in Muslim countries. It is rarely practiced as a means of contraception.

Muslim jurists do not allow any type of permanent contraception except in dire circumstances where there is a serious disease threatening the life or health of the individual."

Vasectomies are not allowed by Muslim jurists. Tubal ligation should not be resorted to in multiparous women who had one or even two caesareans unless the dangers of conception are high.

\section{2) Temporary means of contraception}

These include a wide variety of means and ways ranging from the physiological safe period and coitus interruptus, to mechanical means such as the condom or diaphragm, chemical agents such as spermicides, hormonal means such as contraceptive pills, and intrauterine devices whose mode of action is not known with certainty.

The physiological safe period seems to be the most acceptable by the three cardinal religions; Islam, Christianity and Judaism.

Onanism (coitus interruptus, or 'azl) is allowed in Islam but not in Catholicism. Onan, the grandson of Jacob, was probably the first man to use this method. He spilled his seed on the ground to keep from producing offspring for his deceased brother when he married his wife, Tamar. ${ }^{12}$

The mechanical means pose no problem in Islamic jurisprudence. Similarly, the "pill" is allowed except where it may cause harm. The judicious use of the pill is needed; unfortunately, the "pill" is sold over the counter without prescription in most, if not all, Islamic countries. Indeed, most, if not all, Islamic governments encourage the use of the "pill" and distribute it at nominal prices. This policy is repudiated by Islam. It acts against the Islamic theme of procreation and the goal of increasing the number of Muslims in the world. The Prophet Muhammad (PBUH) ordered Muslims to marry and increase their numbers.

Intrauterine devices (I.U.D.s) pose another problem. Although the mode of action is not clearly known, it is thought that it may act by preventing implantation of the blastula. If such is the case, then it is considered as a type of early abortion, which is not allowed by many Islamic jursits, e.g., Māliki school. ${ }^{3}$

\section{3) Abortion}

Abortion is sometimes used as a means of contraception. This is quite unfortunate and contrary to the aims of contraception. Abortion is practiced widely nowadays for non-medical reasons with at least 50 million abortions carried out annually worldwide. In France and Japan, half of all the pregnancies end in abortion whether carried out legally or illegally." In South Korea, abortion is responsible for a $33 \%$ decrease in the birth rate. ${ }^{\text {s }}$

The Soviet Union was the first country to legalize abortion on demand in 1920. It was banned from 1936 to 1955 , when it was legalized for the second time. ${ }^{14}$

The United Kingdom legalized abortion on demand in the first trimester in 1967; many other countries followed suit. The United States legalized abortion on demand in 1973, resulting in 1.5 million abortions annually. Japan performs 2-3 million abortions every year. ${ }^{14,13}$

Even in the Catholic countries of the Iberian peninsula, where abortion is not legalized yet, the number of abortions is estimated at one million annually. Similarly, in Latin American countries, the 
rate of abortion is very high.

There are no available statistics of abortion procedures carried out in Muslim countries. However, it seems that the incidence of elective abortion is low in comparison with non-Muslim countries. All Muslim countries incriminate abortions carried out for nonmedical reasons, with the exception of Tunisia. ${ }^{18}$

Muslim jurists generally consider abortion prohibited, unless the life or health of the mother is threatened seriously. Congenital anomalies, if detected early in pregnancy, may be considered acceptable reason for allowing abortion by some jurists. ${ }^{17,18}$ Also, many jurists would allow abortion in cases of rape. ${ }^{19}, 20$

However, all Muslim jurists agree that abortion is not allowed if the age of the fetus is 120 days or more (considered from the start of conception, i.e., fertilization)," whether the fetus is malformed or not, or even in case of rape. This is simply because 120 days is considered as the time of ensoulment of the felus.

Some jurists would not allow termination of pregnancy after 40 days of conception, whatever the reason may be, unless the life of the mother is threatened seriously."

Others, who are more stringent, e.g. al-'Imām alGhazāi and al-'Imām Mālik, would not allow abortion at any time after conception unless the life of the mother is threatened seriously."

Modern medical technology, such as ultrasonography, amniocentesis, and chorionic villus biopsy, helps to diagnose many congenital fetal anomalies. These procedures also can determine the gender of the unborn child with varying degrees of accuracy. Once this is known many parents would resort to abortion if the fetus happens to be a female (or the undesired sex). Unfortunately, this practice is gaining popularity in many Asian countries, e.g., India and China. In Mahrashtra, a western state of India, whose capital is Bombay, there are more than 500 so called sex detection clinics. ${ }^{21}$

Until recently, female infanticide was common both in China and India. Since such practice is now penalized by law, people have resorted to the modern version of female infanticide, i.e., miscarriage, which is usually carried out in the second trimester of pregnancy, as it is often difficult to diagnose the sex of the fetus in the first trimester. A second trimester miscarriage is fraught with many complications and poses greater risks to a pregnant woman.

\section{Concluding remarks}

Islam encourages procreation within wedlock without limits; however, most Muslim governments, faced by the problem of overpopulation, encourage the widespread use of contraceptives sometimes by coercion or even compulsion. Contraceptive pills are sold to the public at nominal value, and usually can be obtained over the counter without a medical prescription. This results in many health hazards, as they may be taken by hypertensives, diabetics, patients suffering from varicosities, tumors, liver disease, or women over the age of 35 .

Some Muslim countries such as Saudi Arabia, are sparsely populated. The census of 1974 estimated the population of Saudi Arabia at 7 million, with more than 3 million aliens. ${ }^{23}$ In 1986 the population was estimated at 10 million, Saudis comprising about 6 million, a population density of 3 Saudis $/ \mathrm{Km}^{2}$. In comparison, the density of the population in the United Kingdom is 229 people/ $/ \mathrm{Km}^{2}$. ${ }^{23}$ These figures clearly show that the present policy of encouraging contraception and selling contraceptive pills over the counter should be changed.

There is much need for reassessment of the present policies of Muslim governments regarding contraception. The judicious use of contraception is allowed by Islamic teachings and this judicious use should be encouraged.

The present policy of limiting abortions (first trimester) to medical reasons and rape should continue.

\section{References:}

1. Genesis 1:27-28. The Holy Bible. New International Translation; London, Sydney, and Toronto: Hodder and Soughton, 1890.

2. Glorious Qur'ān, Chapter 4, Verse 4.

3. Glorious Qur'än, Chapter 16, Verse 72.

4. 'Ibn Mājah: "Sunan 'ibn Mājah" (Arabic): Kitāb al Nikāh (Book of Marriage), Numbr 8. Muhammad Fu'ād 'Abdul Bāqi (ed), Cairo, Egypt: 'İsã al Halabì Publishing Company (no date mentioned).

5. Ahmad 'ibn Hanbal: "Musnad Ahmad" (Arabic). Volume 3, Numbers 158, 235. Ahmad Shākir (ed), Cairo, Egypt: Dār al-Ma'ārif Publishing Company (no date mentioned).

6. Ibid, Volume 4, Numbers $349,351$.

7. Sahih al-Bukhārí. Division 62 , "Kitāb al-Nikāh" (Book of Marriage), Chapter 97, Volume 7, p 102. Numbers 136, 137. M. M. Khan (ed), Beirut, Lebanon: Dār al 'Arabiyyah Publishing, Printing and Distribution.

8. Șahih Muslim: Division 5, "Kitāb al-Nikāh" (Book of Marriage), Volume 2, p 732, Numbers 3371-77, 'Abdul Hamid Siddiqi (ed). Sh. Muhammad Ashraf, Publisher and Booksellers, Lahore, Pakistan, 1987.

9. Ahmad 'ibn Hanbal: "Musnad Ahmad" (Arabic), Volume 3, Numbers 51, 53, 313, 383. Ahmad Shakir (ed), Cairo, Egypt: Dar al-Ma' arif Publishing Company (no date mentioned).

10. 'Ibn Mājah: "Sunan 'Ibn Mājah", "Kitāb AlNikāḥ" (Book of Marriage), Number 30, 
Muḥammad Fu'ād 'Abdul Bāqî (ed), Cairo, Egypt: 'Isã al Halabì Publishing Company (no date mentioned).

11. Al-Qaradāwì, Y: "Al-Halāl wal-Harām FilIslam" (The Lawful and the Prohibited in Islam). Translated by Kamal Al-Helbāwy, M. M. Siddique, and Syed Shukry. Indianapolis, IN, USA: American Trust Publications, 1985; pp 198-201.

12. Ref 1; Genesis 38:8-10.

13. Albar M: "Man'ul-Haml waHukmuh Fil-Islām". Al-Muslim al-Mu'ășir Magazine (Arabic), 1984 (1404H); 42(11):91-100.

14. Encyclopedia Britannica, 15th Ed., ChicagoLondon-Paris: Encyclopedia Britannica, Inc.; 1982, 2:1069.

15. Potts M, Diggory P: Textbook of Contraceptive Practice. 2nd Edition, New York: Cambridge University Press, 1983:287, 315.

16. Nazer, I: The Tunisian Experience in Legal
Abortion. Intl J Obstel Gynecol 1979;17:493.

17. Albar, M: The Problem of Abortion (Arabic). 2nd Edition, Jeddah: Saudia Publishing House, 1986:37-45.

18. Ghanim I: Abortion as a Necessity (Arabic). alFaysal Med J 1984;9:61-65.

19. Al-Mashhūr, AR: "Ghāyat Talkhis al-Murād min Fatāwì Ziyād”' (Arabic). Dār al-Ma‘ārif 247, Beirut, Labanon (printed with Bughiat alMustarshidin).

20. Al-Būti, MSR: "Mas'alat Tahdid al-Nasl Wiqāyatan Wa-'ilāgan" (Arabic). Maktabat alFārābi, Beirut, Lebanon, 1976; pp 135-153.

21. Tift, S: Curse Heaven for Little Girls. Time Magazine, Jan. 4, 1988;1:46-47.

22. Encyclopedia Britannica, 15th Edition. Encyclopedia Britannica, Inc., Chicago, 1982: Micropedia 8:920.

23. Ref 14; Micropedia 10:266. 